Egypt. J. of Appl. Sci., 36 (3) 2021

\title{
IMPACT OF STRETCHING WITH AND WITHOUT STABILIZATION EXERCISES ON NECK PAIN AND DISABILITY IN SUBJECTS WITH UPPER CROSSED SYNDROME
} Noha M. El-Badrawy ${ }^{*}$; Yasser M. Aneis ${ }^{* *}$

Hanaa K. Ata ${ }^{* * *}$ and A.E. El-Ganainy $* * *$

"Researcher of physical therapy for Basic Science Department, Faculty of Physical Therapy,Cairo University, Egypt.

**Assistant Professor of Physical Therapy for Basic Science Department, Faculty of Physical Therapy, Cairo University, Egypt.

****ecturer of Physical Therapy for Basic Basic Science Department, Faculty of Physical Therapy,Cairo University, Egypt.

***** Department of Orthopedic surgery, Faculty of Medicine, Mansoura University, Dakhlia, Egypt.

Key words: upper crossed syndrome, stabilization, stretching exercises, neck pain

\section{ABSTRACT}

Objectives: Examine the effect of exercises in treating upper crossed syndrome (UCS).

Methods: Eighteen patients aged from 25-40 years with UCS from both populations. patients were randomly assigned into two equal groups; Group A ( $n=9)$ stabilization exercises and stretching exercises for 30 minutes and Group B $(n=9)$ received stretching exercises only for 15 minutes. Both groups received 1 session/ week for 12 weeks. pain intensity level measured by visual analogue scale (VAS) and functional activity measured by neck disability index (NDI), measurements taken pre-treatment and after 12 weeks of treatment for both groups. Results: VAS and NDI scores showed significant reduction in both groups, but group A showed more improvement than group B. Conclusion: Combined exercises showed considerable changes in treating UCS.

\section{INTRODUCTION}

Neck pain is an important problem affecting musculoskeletal system (Szeto et al., 2005). Individuals with chronic neck pain have altered abnormal postures for prolonged times. Chronic neck pain has the potential to change the biomechanics of the spine (Kim et al., 2015). Patients with neck disorders frequently have forward head posture (Yoo. 2013).

Forward head posture leads to shortening of the posterior neck extensors and anterior neck and shoulder muscles (Lindstrøm et al., 2011). Deep neck flexor stabilizing exercises, mobilization and electrical therapy are considered traditional methods for treating neck pain 
(Helgadottir et al., 2011). Upper cross syndrome (UCS) is a combination of forward head posture and rounded shoulder (RS) (Lynch et al., 2010). UCS leads to dysfunction along different multiple cervical joints and shoulder joint (Kang et al., 2012).

Previous studies used stretching and strengthening exercises, mobilization and manipulation for treating this syndrome (Lynch et al., 2010). The aim of this study is to determine the effect of combined exercise program on UCS patients.

\section{MATERIALS AND METHODS:}

\section{Design, setting, methods, and population}

This randomized controlled trial was conducted at general hospital, Egypt. The study was conducted from March 2018 to August 2019. A written informed consent was signed by all the participants. Eighteen patients were selected to be enrolled into this study after they had fulfilled the inclusion criteria which were participants of both gender aging from 25 to 40 years who demonstrated chronic neck pain for more than 3 months.

Exclusion criteria includes participants older than 40 or younger than 25 years, BMI more than 30, functional or structural scoliosis, psychosocial problem, cognitive impairment, tumor, inflammation and congenital deformity and neurological diseases.

Patients who fulfilled the inclusion criteria of the study were randomly assigned to either; group A, the intervention group $(n=9)$, who received a combined treatment or Group $B$, the control group $(n=9)$, who received stretching exercises.

\section{Outcome measures}

Pain intensity measured by VAS, and functional disability measured by NDI.

\section{Assessments}

Pain intensity

VAS assesses the levels of pain intensity perceived by the patient using a 10-point scale (varying from 0 to 10), in which 0 represents "no pain" and 10 represents the "worst possible pain" (Guru et al., 2013).

Functional disability

The impact of neck pain on the patients' functional activities was determined by the NDI. The index is a self-report questionnaire of the subject's perceived disability (Vernon and Mior, 1991).

\section{Intervention}

The intervention group (group A) received a combination of stretching and stabilization exercises for 30 minutes and Group B received stretching exercises only for 15 minutes. Both groups received 1 session/ week for 12 weeks. 


\section{Stabilization exercise \\ Cervical stabilization exercise}

The patient was lying in supine position, then asked to tuck his or her chin in" and "hold her head up" as though he or she was saving 'yes'. This exercise was repeated for 30 times for 3 sets (Asmaa et al., 2016).

\section{Cervicothoracic stabilization exercise}

The patient was lying prone with both upper limbs beside his/her body, then asked to raise his/her head with chin tucked in. This exercise was repeated for 30 times for 3 sets (Kisner and Colby, 2012).

\section{Stretching exercises}

Stretching was done for upper trapezius, and rhomboids. The rhomboids and the upper trapezius muscles were engaged in selfstretching exercsises. In the self-stretching exercise, the rhomboid was stretched by pulling it laterally and the upper trapezius was stretched by pulling it into cervical flexion. Each repetition was performed for 30 seconds, with a five-second break between each repetition. One exercise set consisted of three repetitions (Evjenth and Hamberg, 1994).

\section{Statistical Analysis}

Multiple pairwise comparison tests were used for NDI measurements and Wilcoxon Signed Ranked tests were used for VAS measurements. For between-group analysis, multiple pairwise comparison tests (post hoc tests) were used for NDI measurements and Mann-Whitney U test was used for VAS measurements. The statistically significant difference was accepted at $\mathrm{p}<0.05$.

\section{RESULTS}

In the baseline evaluation, results revealed that there were nonsignificant differences between the two groups with regard to physical characteristics where $(P>0.05)$, results are given in table 1 .

Table 1. Baseline demographic and clinical characteristics of patients

\begin{tabular}{|l|c|c|c|}
\hline \multicolumn{1}{|c|}{ Variables } & $\begin{array}{c}\text { Group A } \\
\text { Mean } \pm \text { SD }\end{array}$ & $\begin{array}{c}\text { Group B } \\
\text { Mean } \pm \text { SD }\end{array}$ & $P$-value \\
\hline Age (year) & $\mathbf{4 5 . 1 3} \pm 5.5$ & $46.73 \pm 5.49$ & 0.321 \\
\hline Height $(\mathbf{c m})$ & $\mathbf{1 5 6 . 8} \pm 7.45$ & $158.4 \pm 7.7$ & $\mathbf{0 . 5 6 8}$ \\
\hline Weight $(\mathrm{kg})$ & $\mathbf{1 0 5 . 1 3} \pm 10.32$ & $107.66 \pm 9.8$ & $\mathbf{0 . 1 9 0}$ \\
\hline BMI $\left(\mathrm{Kg} / \mathrm{m}^{2}\right)$ & $\mathbf{3 4 . 9 8} \pm 2.21$ & $35.18 \pm 2.79$ & $\mathbf{0 . 3 8 8}$ \\
\hline Onset of neck pain (months) & $\mathbf{5 . 1 5} \pm 1$ & $5 \pm 1.5$ & $\mathbf{0 . 5 9 1}$ \\
\hline
\end{tabular}

SD = Standard Deviation; BMI = Body Mass Index; Level of significance at $P \leq$ 0.05

Regarding NDI, and VAS, there were significant changes in the two groups after 12 weeks of intervention relative to baseline, where $(P<$ $0.001)$, with more improvements in group A Between-group variations were remarkable where $(P<0.001)$, (see table 2$)$. 
Table 2. Changes in NDI and VAS.

\begin{tabular}{|l|l|l|l|}
\hline Variable & Group A $(\mathrm{n}=15)$ & Group B $(\mathrm{n}=15)$ & P value \\
\hline NDI (\%) & & & \\
Baseline & $46.87(32.7-65.0)$ & $52.0(39.6-67.4)$ & 0.209 \\
4 weeks & $4.31(2.35-7.34)$ & $35.81(21.8-44.77)$ & 0.0001 \\
P value & 0.0001 & 0.0001 & \\
\hline VAS & & & \\
Baseline & $8(7.21-9.81)$ & $7(4.5-9.5)$ & \\
4 weeks & $2(1.21-6.11)$ & $3(1.2-6.7)$ & 0.841 \\
P value & 0.0001 & 0.0001 & 0.0001 \\
\hline
\end{tabular}

NDI: neck disability index; VAS: visual analogue scale $(\mathrm{p}<0.05)$.

\section{DISCUSSION}

The results are supported by other studies, some of them used stretching and strengthening exercises for UCS (Lynch et al., 2010). Others used stabilization exercises to restore normal posture of the neck, scapula and shoulder joint (Im et al., 2015).

FHP puts the DNF in a lengthened position, creating a mechanical disadvantage and abnormal motor control of the head and cervical spine. Therefore, more specific training of the DNF through cervical stabilization improves the ability to maintain upright posture of the cervical spine (Chung et al., 2012).

In UCS patients, UT is overactive and we used stretching exercises to normalize its tone while SA and lower trapezius are underactive (Lynch et al., 2010).

Our findings revealed a significant decrease in pain intensity. This improvement of pain seems attributable to the restoration of normal posture of head, neck and shoulder. FHP and FSP could lead to an increase in the stress imposed on articular, muscular, and neural tissues of the neck and upper limb, which could lead to the development of pain depending on the tolerance and adaptation capability of the central nervous system (Kim and Kim. 2016). In addition, repetitive mechanical stress over time could promote the appearance of algogenic substances that could lead to tissue hyperalgesia (Martínez-Merinero et al., 2017).

Due to the abnormal positioning of the head and neck joints and muscles in FHP, this postural disorder can affect neck proprioception (Shaghayegh-Fard et al., 2015). Proprioception is necessary for proper joint function in exercises, occupational and daily activities and helps with motor control, dynamic restrains and increases muscle stiffness and therefore provide joint dynamic stability. The loss of proprioception feedback leads to functional disability (Armstrong et al., 2008). In fact, it can be stated that increased FHP will have more side effects on deep head and neck muscle function, muscle spindles and finally on reaction time, postural control, and postural stability (Armstrong et al., 2005). 


\section{REFERENCES}

Armstrong, B. ; P. McNair and D. Taylor (2008). Head and neck position sense. Sports medicine; 38(2): 101-117.

Armstrong, B.S. ; P.J. McNair and M. Williams (2005). Head and neck position sense in whiplash patients and healthy individuals and the effect of the cranio-cervical flexion action. Clinical Biomechanics; 20(7): 675-684.

Asmaa, M. ; H.O.G. El-Bandrawy and O. Ghareeb (2016). Efficacy of neck stabilization exercises for neck pain complicating pregnancy. IJTRR., 5(5): 122-128.

Chung, S.H. ; G.J. Her ; T Ko and et al., (2012). Effects of exercise on deep cervical flexors in patients with chronic neck pain. $J$ Phys Ther Sci., 24(7): 629-632.

Evjenth, O. and J. Hamberg (1994). Muscle stretching in manual therapy: a clinical manual. Sweden, Alfta Rehab Forlag.

Guru, K. ; N. Praveen and K. Selvamani (2013). Isometric endurance of neck muscles and muscles for scapular positioning in individuals with and without postural neck pain. Internet Journal of Allied Health Sciences and Practice, 11(2): 1-11.

Helgadottir, H. ; E. Kristjansson; E. Einarsson and et al., (2011). Altered activity of the serratus anterior during unilateral arm elevation in patients with cervical disorders. J Electromyogr Kinesiol, 21: 947-953. [Medline] [CrossRef]

Im, B. ; Y. Kim ; Y. Chung and et al. (2015). Effects of scapular stabilization exercise on neck posture and muscle activation in individuals with neck pain and forward head posture. Journal of physical therapy science; 28(3): 951-955.

Kang, J.H. ; R.Y. Park; S.J. Leeand et al., (2012). The effect of the forward head posture on postural balance in long time computer based worker. Ann Rehabil Med., 36(1): 98-104.

Kim, D. ; M. Cho ; Y. Park and et al., (2015). Effect of an exercise program for posture correction on musculoskeletal pain. J Phys

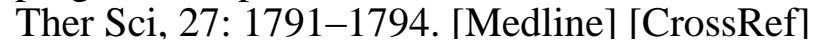

Kim, E.K. and J.S. Kim (2016). Correlation between rounded shoulder posture, neck disability indices, and degree of forward head posture. Journal of physical therapy science; 28(10): 2929-2932.

Kisner, C. and L.A. Colby (2012). Exercise Interventions by Body Region, The Spine and Posture: Structure, Function, Postural Impairments and Management Guidelines: Philadelphia, 398 $400,454$.

Lindstrøm, R. ; J. Schomacher D. Farina and et al., (2011). Association between neck muscle coactivation, pain, and strength 
in women with neck pain. Man Ther, 16: 80-86. [Medline] ¡CrossRef].

Lynch, S.S. ; C.A. Thigpen ; J.P. Mihalik and et al., (2010). The effects of an exercise intervention on forward head and rounded shoulder postures in elite swimmers. British Journal of Sports Medicine, 44(5): 376-381.

Martínez-Merinero, P. ; E. Lluch ; T. Gallezo-Izquierdo and et al., (2017). The influence of a depressed scapular alignment on upper limb neural tissue mechanosensitivity and local pressure pain sensitivity. Musculoskeletal Science and Practice; 29: 60-65.

Shaghayegh-Fard, B. ; A. Ahmadi ; N. Maroufi and et al., (2015). The Evaluation of Cervical Position Sense in Forward Head Posture Subjects and Compares It with Normal Subjects. J Rehabil Med; 16(1): 48-57.

Szeto, G.P. ; L.M. Straker and P.B. O'Sullivan (2005). EMG median frequency changes in the neck-shoulder stabilizers of symptomatic office workers when challenged by different physical stressors. J Electromyogr Kinesiol, 15: 544-555. [Medline] [CrossRef]

Vernon, H. and S. Mior (1991). The Neck Disability Index: a study of reliability and validity. Journal of Manipulative and Physiological Therapeutics, 14(7): 409-415.

Yoo, W.G. (2013). Effect of the neck retraction taping (NRT) on forward head posture and the upper trapezius muscle during computer work. J Phys Ther Sci, 25: 581-582. [Medline] [CrossRef]

$$
\begin{aligned}
& \text { تأثير تمارين الإطالة مع ويدون تمارين التثبيت على آلام الرقبة والإعاقة في } \\
& \text { الأشخاص المصابين بمتلازمة التقاطع العلوي } \\
& \text { ن*** نها محمد البدراوي * ياسر محمد أنيس ** هناء قناوى عطا } \\
& \text { **** عبد الرحمن احمد الجناينى } \\
& \text { " *احث العلاج الطبيعي بقسم العلوم الأساسية بكلية العلاج الطبيعي، جامعة القاهرة ، مصر. }
\end{aligned}
$$

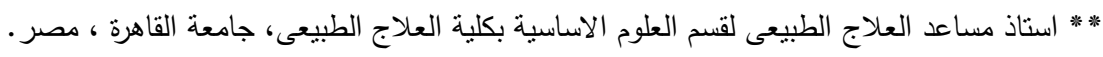

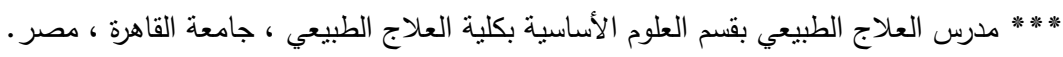

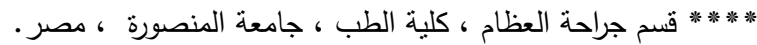

$$
\begin{aligned}
& \text { خلاصة } \\
& \text { الأهداف: فحص نأثثر التمارين في علاج متلازمة الصليب العلوي (UCS). }
\end{aligned}
$$

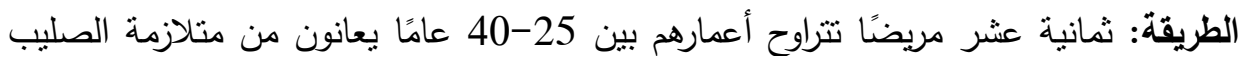

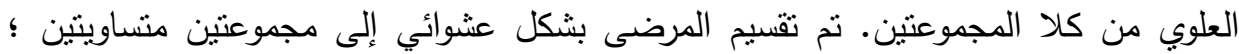




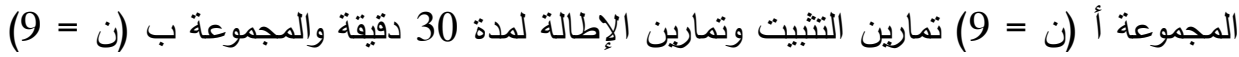

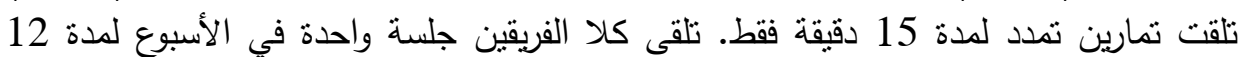

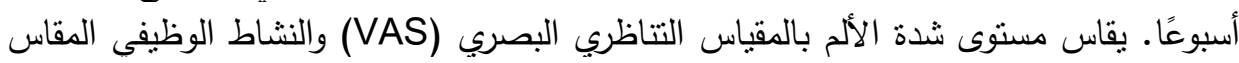

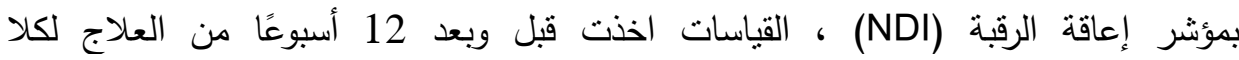

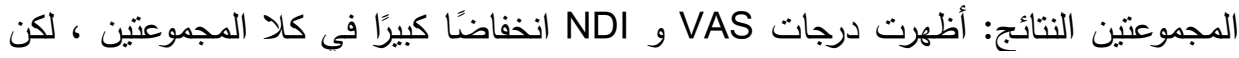
المجموعة A أظهرت تحسنًا أكبر من المجموعة B. الخهات الخهاصة: أظهرت التمارين المشتركة

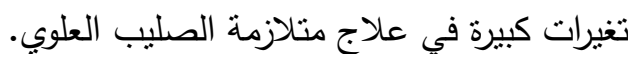
الكلمات الدالة: متلازمة الصليب العلوي ، التتبيت ، تمارين التمدد ، آلام الرقبة 